\title{
Asuhan Keperawatan Jiwa Pada Tn, Y Dengan Masalah Gangguan Proses Pikir: Waham Kebesaran
}

\author{
J Alex C Tumanggor \\ jamslencandra@gmail.com
}

\section{BAB I \\ LATAR BELAKANG}

\subsection{Latar Belakang}

Skizofrenia merupakan sekelompok reaksi psikotik yang memengaruhi berbagai area fungsi individu, termasuk cara berpikir, berkomunikasi, menerima, menginterpretasikan realitas, merasakan dan menunjukkan emosi yang ditandai dengan pikiran kacau, waham, halusinasi, dan perilaku aneh (Pardede, et al, 2015). Skizofrenia merupakan gangguan mental berat dan kronis yang menyerang 20 juta orang di seluruh dunia (WHO, 2019). Indonesia berdasarkan hasil Riskesdas (2018) didapatkan estimasi prevalensi orang yang pernah menderita skizofrenia di Indonesia sebesar 1,8 per 1000 penduduk. (Pardede, Simanjuntak, \& Laia, 2020)

Skizofrenia adalah sekelompok gangguan psikotik dengan distorsi khas proses pikir, kadang-kadang mempunyai perasaan bahwa dirinya sedang dikendalikan oleh kekuatan dari luar dirinya, waham yang kadang-kadang aneh, gangguan persepsi, afek abnormal yang terpadu dengan situasi nyata atau sebenarnya, dan autisme. Skizofrenia merupakan gangguan psikotik yang paling sering. Hampir $1 \%$ penduduk di dunia menderita skizofrenia selama hidup mereka. Gejala skizofrenia biasanya muncul pada usia remaja akhir atau dewasa muda. Onset pada laki-laki biasanya antara 15-25 tahun dan pada perempuan antara 25-35 tahun. Prognosis biasanya lebih buruk pada laki-laki bila dibandingkan denganperempuan. Onset setelah umur 40 tahun jarang terjadi.(Zahnia \& Sumekar, 2016)

Waham atau delusi merupakan keyakinan palsu yang timbul tanpa stimulus luar yang cukup dan mempunyai ciri-ciri sebagai berikut: tidak realistik, 
tidak logis, menetap, egosentris, diyakini kebenarannya oleh penderita, tidak dapat dikoreksi, dihayati oleh penderita sebagai hal yang nyata, penderita hidup dalam wahamnya itu, keadaan atau hal yang diyakini itu bukan merupakan bagian sosiokultural setempat. Waham bizzare merupakan waham yang aneh dimana terdapat pengalaman inderawi yang tidak wajar, Yang bermakna sangat khas bagi dirinya, biasa bersifat mistik atau mukjizat. Berdasarkan DSM IV, waham bizarre dianggap sebagai kriteria yang cukup untuk mendiagnostik skizofrenia. Berdasarkan penelitian yang dilakukan Sreeja de et al. (2013), didapatkan prevalensi waham bizarre pada pasien skizofrenia adalah 2,56\%. Lima hal yang dinilai adalah, kejadian yang tidak mungkin terjadi, sensasi tubuh, perubahan identitas, seksual, dan agama.(Zukna \& Lisiswanti 2017)

Gangguan orientasi realitas atau waham merupakan gangguan yang mempengaruhi perubahan proses pikir yang dapat ditangani secara medis maupun keperawatan. Asuhan keperawatan pada kasus waham dapat disusun sesuai rencana tindakan keperawatan dan berdasarkan strategi pelaksanaan (SP). Beberapa rencana tindakan yang telah disusun berdasarkan SP yaitu membantu orientasi realitas, mendiskusikan kebutuhan yang belum terpenuhi, membantu pasien memenuhi kebutuhannya, mendiskusikan dan melatih kemampuan yang dimiliki, dan memberikan pendidikan kesehatan tentang penggunaan obat secara teratur. Rencana kegiatan yang telah dibuat kemudian disusun sesuai Strategi Pelaksanaan Tindakan Keperawatan.(Fitria \& Sofian 2017).

Dalam beberapa penelitian dijelaskan bahwa orientasi realita dapat meningkatkan fungsi perilaku. Pasien perlu dikembalikan pada realita bahwa hal-hal yang dikemukakan tidak berdasarkan fakta dan belum dapat diterima orang lain dengan tidak mendukung ataupun membantah waham. Tidak jarang dalam proses ini pasien mendapatkan konfrontasi dari lingkungan terkait pemikiran dan keyakinannya yang tidak realistis. Hal tersebut akan memicu agresifitas pasien waham. Reaksi agresif ini merupakan efek dari besarnya intensitas waham yang dialami pasien. Salah 
satu cara untuk mengontrol perilaku agresif dari pasien waham yaitu dengan memberi asuhan keperawatan jiwa (Keliat, 2019)..

Data yang diperoleh dari Medical Record Yayasan Pemenang Jiwa Sumatera tahun 2021, pasien yang menderita skizofrenia sebanyak 75 Orang. Dari jumlah pasien tersebut yang menjadi subjek di pembuatan askep ini adalah 1 orang dengan pasien gangguan proses pikir : Waham (Waham Kebesaran) berinisial Tn. Y. Maka tujuan asuhan keperawatan yang akan di lakukan ialah untuk mengajarkan strategi pelaksanaan Waham pada Tn. Y.

\subsection{Rumusan Masalah}

Berdasarkan masalah yang telah di paparkan pada latar belakang maka rumusan masalah dalam askep ini yaitu asuhan keperawatan jiwa dengan masalah gangguan proses pikir: waham kebesaran pada tn ,y di yayasan pemenang jiwa

\subsection{Tujuan Penulisan}

\subsection{Tujuan Umum}

Maka tujuan asuhan keperawatan yang akan dilakukan ialah untuk mengajarkan standar pelaksanaan gangguan proses pikir:waham dan Tn.Y mampu melaksanakan.

\subsubsection{Tujuan Khusus}

Setelah melakukan asuhan keperawatan kepada pasien dengan

Waham Kebesaran, mahasiswa/i diharapkan mampu :

1. Mahasiswa mampu mengetahui defenisi, penyebab, tanda dan gejala, rentang respon dan penatalaksanaan pada pasien Waham Kebesaran

2. Mahasiswa mampu melakukan pengkajian, analisa data pada Tn. y dengan Waham Kebesaran di Yayasan Pemenang Jiwa Sumatera.

3. Mahasiswa mampu menegakkan diagnosa keperawatan pada Tn. Y dengan Waham Kebesaran di Yayasan Pemenang Jiwa Sumatera.

4. Mahasiswa mampu menetapkan intervensi keperawatan pada 
Tn. Y dengan Waham Kebesaran di Yayasan Pemenang Jiwa Sumatera.

5. Mahasiswa mampu melakukan implementasi keperawatan pada Tn.Y dengan Waham Kebesaran di Yayasan Pemenang Jiwa Sumatera.

6. Mahasiswa mampu mengevaluasi hasil asuhan keperawatan pada Tn. Y dengan Waham Kebesaran di Yayasan Pemenang Jiwa Sumatera.

7. Mahasiswa mampu mendokumentasikan pada Tn. Y dengan Waham Kebesaran di Yayasan Pemenang Jiwa Sumatera.

\subsection{Manfaat}

1. Pasien

Diharapkan tindakan yang telah di ajakarkan dapat di terapkan secara mandiri untuk mengontrol emosi dan untuk mendukung kelangsungan kesehatan pasien.

2. Yayasan Pemenang Jiwa Sumatera.

Diharapkan dapat menjadi acuan dalam menanganin atau dalam memberikan pelayanan kepada pasien dengan gangguan jiwa dengan perilaku kekerasan di Yayasan Pemenang Jiwa Sumatera 


\section{BAB 2 \\ TINJAUAN TEORITIS}

\subsection{Konsep Waham}

\subsubsection{Pengertian waham}

Waham adalah keyakinan yang salah yang didasarkan oleh kesimpulan yang salah tentang realita eksternal dan dipertahankan dengan kuat. Waham merupakan gangguan dimana penderitanya memiliki rasa realita yang berkurang atau terdistorsi dan tidak dapat membedakan yang nyata dan yang tidak nyata (Victoryna, 2020). Waham adalah suatu keyakinan yang salah yang dipertahankan secara kuat/terus menerus, tetapi tidak sesuai dengan keyakinan. Penyangkalan, digunakan untuk menghindari kesadaran dan kenyataan yang menyakitkan. Proyeksi digunakan untuk melindungi diri dari mengenal impuls yang tidak dapat diterima dari dirinya sendiri (Nurarif \& Kusuma, 2015).

\subsubsection{Etiologi}

Menurut World Health Organization (2016) secara medis ada banyak kemungkinan penyebab waham, termasuk gangguan neurodegeneratif, gangguan sistem saraf pusat, penyakit pembuluh darah, penyakit menular, penyakit metabolisme, gangguan endokrin, defisiensi vitamin, pengaruh obat-obatan, racun, dan zat psikoaktif.

1. Faktor Predisposisi

a. Genetis : diturunkan, adanya abnormalitas perkembangan sistem saraf yang berhubungan dengan respon biologis yang maladaptif.

b. Neurobiologis : adanya gangguan pada korteks pre frontal dan korteks limbic

c. Neurotransmitter : abnormalitas pada dopamine, serotonin dan glutamat. 
d. Psikologis : ibu pencemas, terlalu melindungi, ayah tidak peduli.

2. Faktor Presipitasi

a. Proses pengolahan informasi yang berlebihan

b. Mekanisme penghantaran listrik yang abnormal.

c. Adanya gejala pemicu

Pemicu merupakan prekursor dan stimulus yang yang sering menunjukkan episode baru suatu penyakit. Pemicu yang biasa terdapat pada respon neurobiologik yang maladaptif berhubungan dengan kesehatan. Lingkungan, sikap dan perilaku individu (Direja, 2011)

\subsubsection{Rentang Respon Neuroligis}

Menurut Keliat (2016), rentang respon waham sebagai berikut :

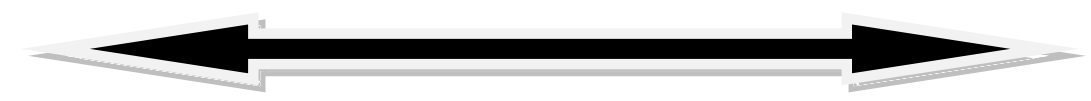

Respon adaptif

Respon Maladtif

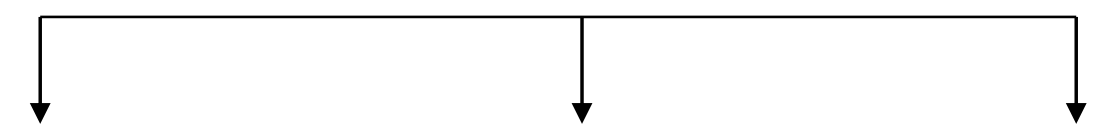

$\begin{array}{ccl}\text { Berpikir logis } & \text { Pikiran sesekali terdistorsi } & \text { Ganguan } \\ \text { Presepsi akurat } & \text { ilusi reaksi emosional } & \text { pemikiran /waham } \\ \text { Emosi konsisten } & \text { berlebiihan atau tidak } & \text { halusinasi kesulitan } \\ \text { dengan pengalaman } & \text { berreaksi perilaku aneh } & \text { pengolahan emosi } \\ \text { prilaku sesuai } & \text { atau pewnarikan } & \text { perilaku kacau } \\ \text { berhubungan } & \text { tidak biasasosial } & \text { isolasi sosial }\end{array}$

\section{Gambar 2.1}

Rentang respon waham 


\subsubsection{Tanda dan Gejala}

Menurut Herman (2011 dalam Prakasa, 2020) bahwa tanda dan gejala gangguan proses pikir waham terbagi menjadi 8 gejala yaitu, menolak makan, perawatan diri, emosi, gerakan tidak terkontrol, pembicaraan tidak sesuai, menghindar, mendominasi pembicaraan, berbicara kasar.

\section{Waham Kebesaran}

a. DS : Pasien mengatakan bahwa ia adalah presiden, Nabi, Wali, artisdan lainnya yang tidak sesuai dengan kenyataan dirinya.

b. DO : Perilaku pasien tampak seperti isi wahamnya, inkoheren (gagasan satu dengan yang lain tidak logis), tidak berhubungan, secara keseluruhan tidak dapat dimengertim pasien mudah marah dan pasien mudah tersinggung

\section{Waham Curiga}

a. DS : Pasien curiga dan waspada berlebih pada orang tertentu,Pasien mengatakan merasa diintai dan akan membahayakan dirinya.

b. DO : Pasien tampak waspada,Pasien tampak menarik diri,Perilaku pasien tampak seperti isi wahamnya ,Inkoheren (gagasan satu dengan yang lain tidak logis, tidak berhubungan, secara keseluruhan tidak dapat dimengerti )

3. Waham Agama

a. DS : Pasien yakin terhadap suatu agama secara berlebihan, diucapkan berulang-ulang tetapi tidak sesuai dengan kenyataan.

b. DO : Perilaku pasien tampak seperti isi wahamnya ,Pasien tampak bingung karena harus melakukan isi wahamnya,Inkoheren (gagasan satu dengan yang lain tidak logis, tidak berhubungan, secara keseluruhan tidak dapat dimengerti)

4. Waham Somatik

a. DS : Pasien mengatakan merasa yakin menderita penyakit fisik ,Pasien mengatakan merasa khawatir sampai panic 
b. DO : Perilaku pasien tampak seperti isi wahamnya ,Inkoheren ( gagasan satu dengan yang lain tidak logis, tidak berhubungan, secara keseluruhan tidak dapat dimengerti )Pasien tampak bingung ,Pasien mengalami perubahan pola tidur, Pasien kehilangan selera makan

5. Waham Nihilistik

a. DS : Pasien mengatakan bahwa dirinya sudah meninggal dunia, diucapkan berulang-ulang tetapi tidak sesuai dengan kenyataan.

b. DO : Perilaku pasien tampak seperti isi wahamnya ,Inkoheren (gagasan satu dengan yang lain tidak logis, tidak berhubungan, secara keseluruhan tidak dapat dimengerti ), Pasien tampak bingung, Pasien mengalami perubahan pola tidur, Pasien kehilangan selera makan

6. Waham Bizzare

a. Sisip Pikir :

1) DS : Pasien mengatakan ada ide pikir orang lain yang disisipkan dalam pikirannya yang disampaikan secara berulang dan tidak sesuai dengan kenyataan,Pasien mengatakan tidak dapat mengambil keputusan

2) DO : Perilaku pasien tampak seperti isi wahamnya ,Pasien tampak bingung, Inkoheren (gagasan satu dengan yang lain tidak logis, tidak berhubungan, secara keseluruhan tidak dapat dimengerti), Pasien mengalami perubahan pola tidur

b. Siar Pikir

1) DS :Pasien mengatakan bahwa orang lain mengetahui apa yang dia pikirkan yang dinyatakan secara berulang dan tidak sesuai dengan kenyataan,Pasien mengatakan merasa khawatir sampai panik, Pasien tidak mampu mengambil keputusan

2) DO : Pasien tampak bingung, Perilaku pasien tampak seperti isi wahamnya, Inkoheren (gagasan satu dengan 
yang lain tidak logis, tidak berhubungan, secara keseluruhan tidak dapat dimengerti) ,Pasien tampak waspada ,Pasien kehilangan selera makan

c. Kontrol Pikir

1) DS : -Pasien mengatakan pikirannya dikontrol dari luar, Pasien tidak mampu mengambil keputusan

2) DO : Perilaku pasien tampak seperti isi wahamnya,Pasien tampak bingung, Pasien tampak menarik diri ,Pasien mudah tersinggung ,Pasien mudah marah ,Pasien tampak tidak bisa mengontrol diri sendiri ,Pasien mengalami perubahan pola tidur ,Inkoheren (gagasan satu dengan yang lain tidak logis, tidak berhubungan, secara keseluruhan tidak dapat dimengerti)

\subsubsection{Fase Waham}

Menurut Eriawan (2019) Proses terjadinya waham dibagi menjadi enam yaitu :

a. Fase Lack of Human need

Waham diawali dengan terbatasnya kebutuhan-kebutuhan pasien baik secara fisik maupun psikis. Secara fisik pasien dengan waham dapat terjadi pada orang-orang dengan status sosial dan ekonomi sangat terbatas. Biasanya pasien sangat miskin dan menderita. Keinginan ia untuk memenuhi kebutuhan hidupnya mendorongnya untuk melakukan kompensasi yang salah. Ada juga pasien yang secara sosial dan ekonomi terpenuhi tetapi kesenjangan antara Reality dengan selfideal sangat tinggi. Misalnya ia seorang sarjana tetapi menginginkan dipandang sebagai seorang dianggap sangat cerdas, sangat berpengalaman dan diperhitungkan dalam kelompoknya. Waham terjadi karena sangat pentingnya pengakuan bahwa ia eksis di dunia ini. Dapat dipengaruhi juga oleh rendahnya penghargaan saat tumbuh kembang (life span history). 
b. Fase lack of self esteem

Tidak ada tanda pengakuan dari lingkungan dan tingginya kesenjangan antara self ideal dengan self reality (kenyataan dengan harapan) serta dorongan kebutuhan yang tidak terpenuhi sedangkan standar lingkungan sudah melampaui kemampuannya. Misalnya, saat lingkungan sudah banyak yang kaya, menggunakan teknologi komunikasi yang canggih, berpendidikan tinggi serta memiliki kekuasaan yang luas, seseorang tetap memasang self ideal yang melebihi lingkungan tersebut. Padahal self reality-nya sangat jauh. Dari aspek pendidikan pasien, materi, pengalaman, pengaruh, support system semuanya sangat rendah.

c. Fase control internal external

Pasien mencoba berfikir rasional bahwa apa yang ia yakini atau apa- apa yang ia katakan adalah kebohongan, menutupi kekurangan dan tidak sesuai dengan kenyataan. Tetapi menghadapi kenyataan bagi pasien adalah sesuatu yang sangat berat, karena kebutuhannya untuk diakui, kebutuhan untuk dianggap penting dan diterima lingkungan menjadi prioritas dalam hidupnya, karena kebutuhan tersebut belum terpenuhi sejak kecil secara optimal. Lingkungan sekitar pasien mencoba memberikan koreksi bahwa sesuatu yang dikatakan pasien itu tidak benar, tetapi hal ini tidak dilakukan secara adekuat karena besarnya toleransi dan keinginan menjaga perasaan. Lingkungan hanya menjadi pendengar pasif tetapi tidak mau konfrontatif berkepanjangan dengan alasan pengakuan pasien tidak merugikan orang lain.

d. Fase environment support

Adanya beberapa orang yang mempercayai pasien dalam lingkungannya menyebabkan pasien merasa didukung, lama kelamaan pasien menganggap sesuatu yang dikatakan tersebut sebagai suatu kebenaran karena seringnya diulang-ulang. Dari sinilah mulai terjadinya kerusakan kontrol diri dan tidak 
berfungsinya norma ( Super Ego ) yang ditandai dengan tidak ada lagi perasaan dosa saat berbohong.

e. Fase comforting

Pasien merasa nyaman dengan keyakinan dan kebohongannya serta menganggap bahwa semua orang sama yaitu akan mempercayai dan mendukungnya. Keyakinan sering disertai halusinasi pada saat pasien menyendiri dari lingkungannya. Selanjutnya pasien lebih sering menyendiri dan menghindar interaksi sosial (Isolasi sosial).

f. Fase improving

Apabila tidak adanya konfrontasi dan upaya-upaya koreksi, setiap waktu keyakinan yang salah pada pasien akan meningkat. Tema waham yang muncul sering berkaitan dengan traumatik masa lalu atau kebutuhan-kebutuhan yang tidak terpenuhi (rantai yang hilang). Waham bersifat menetap dan sulit untuk dikoreksi. Isi waham dapat menimbulkan ancaman diri dan orang lain. Penting sekali untuk mengguncang keyakinan pasien dengan cara konfrontatif serta memperkaya keyakinan relegiusnya bahwa apaapa yang dilakukan menimbulkan dosa besar serta ada konsekuensi sosial.

\subsubsection{Jenis Waham}

Menurut Stuart (2005, dalam Prakasa, 2020) jenis waham yaitu :

a. Waham kebesaran: individu meyakini bahwa ia memiliki kebesaran atau kekuasaan khusus yang diucapkan berulang kali, tetapi tidak sesuai kenyataan. Misalnya, "Saya ini pejabat di separtemen kesehatan lho!" atau, "Saya punya tambang emas.” B

b. Waham curiga: individu meyakini bahwa ada seseorang atau kelompok yang berusaha merugikan/mencederai dirinya dan siucapkan berulang kali, tetapi tidak sesuai kenyataan. Contoh, "Saya tidak tahu seluruh saudara saya ingin menghancurkan hidup saya karena mereka iri dengan kesuksesan saya.” 
c. Waham agama: individu memiliki keyakinan terhadap terhadap suatu agama secara berlebihan dan diucapkan berulang kali, tetapi tidak sesuai kenyataan. Contoh, "Kalau saya mau masuk surga, saya harus menggunakan pakaian putih setiap hari."

d. Waham somatic: individu meyakini bahwa tubuh atau bagian tubuhnya terganggu atau terserang penyakit dan diucapkan berulang kali, tetapi tidak sesuai dengan kenyataan. Misalnya, "Saya sakit kanker." (Kenyataannya pada pemeriksaan laboratorium tidak ditemukan tanda-tanda kanker, tetapi pasien terus mengatakan bahwa ia sakit kanker).

e. Waham nihilistik: Individu meyakini bahwa dirinya sudah tidak ada di dunia/meninggal dan diucapkan berulang kali, tetapi tidak sesuai kenyataan. Misalnya, "Ini kan alam kubur ya, semua yang ada disini adalah roh-roh".

f. Waham sisip pikir : keyakinan pasien bahwa ada pikiran orang lain yang disisipkan ke dalam pikirannya.

g. Waham siar pikir : keyakinan pasien bahwa orang lain mengetahui apa yang dia pikirkan walaupun ia tidak pernah menyatakan pikirannya kepada orang tersebut

h. Waham kontrol pikir : keyakinan pasien bahwa pikirannya dikontrol oleh kekuatan di luar dirinya.

\subsubsection{Penatalaksanaan Medis}

Menurut Prastika (2014) penatalaksanaan medis waham antara lain :

1. Psikofarmalogi

a. Litium Karbonat Jenis litium yang paling sering digunakan untuk mengatasi gangguan bipolar, menyusul kemudian litium sitial. Litium masih efektif dalam menstabilkan suasana hati pasien dengan gangguan bipolar. Gejala hilang dalam jangka waktu 1-3 minggu setelah minum obat juga digunakan untuk mencegah atau mengurangi intensitas serangan ulang pasien bipolar dengan riwayat mania. 
b. Haloperidol Obat antipsikotik (mayor tranquiliner) pertama dari turunan butirofenon. Mekanisme kerja yang tidak diketahui. Haloperidol efektif untuk pengobatan kelainan tingkah laku berat pada anak-anak yang sering membangkang dan eksplosif. Haloperidol juga efektif untuk pengobatan jangka pendek, pada anak yang hiperaktif juga melibatkan aktivitas motorik berlebih memiliki kelainan tingkah laku seperti: Impulsif, sulit memusatkan perhatian, agresif, suasana hati yang labil dan tidak tahan frustasi.

c. Karbamazepin Karbamazepin terbukti efektif, dalam pengobatan kejang psikomotor, dan neuralgia trigeminal. Karbamazepin secara kimiawi tidak berhubungan dengan obat antikonvulsan lain atau obat lain yang digunakan untuk mengobati nyeri pada neuralgia trigeminal

1) Pasien hiperaktif atau agitasi anti psikotik potensi rendah Penatalaksanaan ini berarti mengurangi dan menghentikan agitasi untuk pengamanan pasien. Hal ini menggunakan penggunaan obat anti psikotik untuk pasien waham.

2) Antipsikosis atipikal (olanzapin, risperidone). Pilihan awal Risperidone tablet $1 \mathrm{mg}, 2 \mathrm{mg}$, $3 \mathrm{mg}$ atau Clozapine tablet 25mg, 100mg. Keuntungan

3) Tipikal (klorpromazin, haloperidol), klorpromazin 25100mg. Efektif untuk menghilangkan gejala positif.

4) Penarikan diri selama potensi tinggi seseorang mengalami waham. Dia cenderung menarik diri dari pergaulan dengan orang lain dan cenderung asyik dengan dunianya sendiri (khayalan dan pikirannya sendiri). Oleh karena itu, salah satu penatalaksanaan pasien waham adalah penarikan diri yang potensial, Hal ini berarti penatalaksanaannya penekanankan pada gejala dari waham itu sendiri, yaitu gejala penarikan diri yang berkaitan dengan kecanduan morfin biasanya sewaktu- 
waktu sebelum waktu yang berikutnya, penarikan diri dari lingkungan sosial

5) ECT tipe katatonik Electro Convulsive Therapy (ECT) adalah sebuah prosedur dimana arus listrik melewati otak untuk pelatihan kejang singkat. Hal ini menyebabkan perubahan dalam kimiawi otak yang dapat mengurangi penyakit mental tertentu, seperti skizofrenia katatonik. ECT bisa menjadi pilihan jika gejala yang parah atau jika obat-obatan tidak membantu meredakan episode katatonik.

6) Psikoterapi Walaupun obat-obatan penting untuk mengatasi pasien waham, namun psikoterapi juga penting. Psikoterapi mungkin tidak sesuai untuk semua orang, terutama jika gejala terlalu berat untuk terlibat dalam proses terapi yang memerlukan komunikasi dua arah. Yang termasuk dalam psikoterapi adalah terapi perilaku, terapi kelompok, terapi keluarga, terapi supportif.

\subsection{Konsep Asuhan Keperawatan Jiwa}

\subsubsection{Pengkajian}

Pengkajian Keperawatan Pengkajian adalah sebagai dasar utama dari proses keperawatan. Tahap pengkajian terdiri dari pengumpulan data dan perumusan masalah klien. Data yang dikumpulkan melalui data biologis, psikologis, sosial dan spiritual (Saputri \& Mar'atus, 2021) Menurut Kaplan dan Sadock (1997, dalam Yusuf (2015) beberapa hal yang harus dikaji antara lain sebagai berikut.

a. Identitas Klien Informan Perawat yang merawat klien melakukan perkenalan dan kontrak dengan klien tentang: Nama klien, panggilan klien, Nama perawat, tujuan, waktu pertemuan, topik pembicaraan.

b. Alasan Masuk Tanyakan pada keluarga atau klien hal yang menyebabkan klien dan keluarga datang ke Rumah Sakit, yang 
telah dilakukan keluarga untuk mengatasi masalah dan perkembangan yang dicapai.

c. Riwayat Kesehatan Sekarang Tanyakan pada klien atau keluarga, apakah klien pernah mengalami gangguan jiwa pada masa lalu, pernah melakukan, mengalami, penganiayaan fisik, seksual, penolakan dari lingkungan, kekerasan dalam keluarga dan tindakan kriminal.

d. Aspek Fisik Mengukur dan mengobservasi tanda-tanda vital: TD, nadi, suhu, pernafasan. Ukur tinggi badan dan berat badan, kalau perlu kaji fungsi organ kalau ada keluhan.

e. Aspek Psikososial Membuat genogram yang memuat paling sedikit tiga generasi yang dapat menggambarkan hubungan klien dan keluarga, masalah yang terkait dengan komunikasi, pengambilan keputusan dan pola asuh.

f. Konsep Diri.

1) Citra tubuh Biasanya pasien dengan waham miliki perasaan negatif terhadap diri sendiri.

2) Identitas diri Pada pasien dengan waham kebesaran misalnya mengaku seorang polisi padahalkenyataan nya tidak benar.

3) Peran Klien Berperan sebagai kepala keluarga dalam keluarganya.

4) Ideal diri Klien

berharap agar bisa cepat keluar dari RSJ karena ia bosan sudah lama di RSJ.

5) Harga diri

Adanya gangguan konsep diri :harga diri rendah karena perasaan negatif terhadapdiri sendiri,hilangnya rasa percaya diri dan merasa gagal mencapai tujuan.

6) Hubungan Sosial Pasien dengan waham biasanya memiliki hubungan sosial yang tidak haramonis.

7) Spiritual Nilai dan Keyakinan : Biasanya pada pasien dengan waham agama meyakini agamanya secara berlebihan. 
Kegiatan Ibadah Biasanya pada pasien dengan waham agama melakukan ibadah secara berlebihan.

8) Status Mental.

9) Penampilan

Pada pasien waham biasanya penampilan nya sesuai dengan waham yang ia rasakan.Misalnya pada waham agama berpakaian seperti seorang ustadz.

10) Pembicaraan Pada pasien waham biasanya pembicaraan nya selalu mengarah ke wahamnya,bicara cepat,jelas tapi berpindah-pindah, isi pembicaraan tidak sesuai dengankenyataan.

11) Aktivitas Motorik Pada waham kebesaran bisa saja terjadi perubahan aktivitas yang berlebihan.

12) Alam Perasaan

\subsubsection{Diagnosa Keperawatan}

Menurut Damaiyanti (2012) Masalah keperawatan yang sering muncul pada pasien waham adalah:

1) Kerusakan komunikasi verbal dan

2) Harga diri rendah kronik..

\subsubsection{Rencana Keperawatan}

Rencana Keperawatan yang diberikan pada pasien tidak hanya berfokus pada masalah waham sebagai diagnosa penyerta lain. Hal ini dikarenakan tindakan yang dilakukan saling berkontribusi terhadap tujuan akhir yang akan dicapai. Rencana tindakan keperawatan pada pasien dengan diagnosa gangguan proses pikir : waham yaitu (Keliat, 2009) :

1. Bina hubungan saling percaya Sebelum memulai mengkaji pasien dengan waham, saudara harus membina hubungan saling percaya terlebih dahulu agar pasien merasa aman dan nyaman saat berinteraksi dengan saudara. Tindakan yang harus saudara lakukan dalam rangka membina hubungan saling percaya adalah: 

a. Mengucapkan salam terapeutik
b. Berjabat tangan
c. Menjelaskan tujuan interaksi

2. Bantu orientasi realita

a. Tidak mendukung atau membantah waham pasien

b. Yakinkan pasien berada dalam keadaan aman

c. Observasi pengaruh waham terhadap aktivitas sehari-hari

d. Jika pasien terus menerus membicarakan wahamnya dengarkan tanpa memberikan dukungan atau menyangkal sampai pasien berhenti membicarakannya

e. Berikan pujian bila penampilan dan orientasi pasien sesuai dengan realitas.

f. Diskusikan kebutuhan psikologis/emosional yang tidak terpenuhi sehingga menimbulkan kecemasan, rasa takut dan marah.

g. Tingkatkan aktivitas yang dapat memenuhi kebutuhan fisik dan emosional pasien

h. Berdikusi tentang kemampuan positif yang dimiliki

i. Bantu melakukan kemampuan yang dimiliki

j. Berdiskusi tentang obat yang diminum

k. Melatih minum obat yang benar.

\subsubsection{Implementasi keperawatan}

Implementasi disesuaikan dengan rencana tindakan keperawatan. Pada situasi nyata sering pelaksanaan jauh berbeda dengan rencana hal ini terjadi karena perawat belum terbiasa menggunakan rencana tertulis dalam melaksanakan tindakan keperawatan Dalami (2009). Adapun pelaksanaan tindakan keperawatan jiwa dilakukan berdasarkan Strategi Pelaksanaan (SP) yang sesuai dengan masingmasing maslaah utama. Pada masalah gangguan proses pikir : waham terdapat 4 macam SP yaitu :

SP 1 Pasien : Membina hubungan saling percaya, latihan orientasi realita : orientasi orang, tempat, dan waktu serta lingkungan sekitar. 
SP 2 Pasien : Mengajarkan cara minum obat secara teratur

SP 3 Pasien : Mengidentifikasi kebutuhan yang tidak terpenuhi dan cara memenuhi kebutuhan; mempraktekkan pemenuhan kebutuhan yang tidak terpenuhi

SP 4Pasien :Mengidentifikasi kemampuan positif pasien yang dimiliki dan membantu mempraktekkannya

\subsubsection{Evaluasi}

Menurut Yusuf (2015) evaluasi yang diiharapkan pada asuhan keperawatan jiwa dengan gangguan proses pikir adalah:

1. Pasien mampu melakukan hal berikut:

a. Mengungkapkan keyakinannya sesuai dengan kenyataan.

b. Berkomunikasi sesuai kenyataan.

c. Menggunakan obat dengan benar dan patuh.

2. Keluarga mampu melakukan hal berikut:

a. Membantu pasien untuk mengungkapkan keyakinannya sesuai kenyataan.

b. Membantu pasien melakukan kegiatan-kegiatan sesuai dengan kemampuan dan kebutuhan pasien.

c. Membantu pasien menggunakan obat dengan benar dan patuh. 


\subsection{Identitas Pasien}

\section{BAB 3 \\ TINJAUAN KASUS}

$\begin{array}{lll}\text { Inisial } & : \text { Tn.Y } \\ \text { Jenis kelamin } & : \text { Laki-Laki } \\ \text { Umur } & : \text { Tahun } \\ \text { Agama } & : \text { Krinten } \\ \text { Status } & : \text { Lajang } \\ \text { Tanggal pengkajian } & : 10 \text { maret } 2021 \\ \text { Informant } & : \text { komunikasi dengan pasien dan pegawai Yayasan } \\ & & \text { pemenang jiwa }\end{array}$

\subsection{Alasan Masuk Yayasan Pemenang Jiwa}

Alasan pasien masuk yayasan pemenangan jiwa adalah pasien mengatakan di bawa oleh saudaranya, karena sering melihat mahluk halus ketika mau tidur dan paien sering stres karena usaha ketring yang mau dibuat gagal.

\subsection{Faktor Predisposisi}

Pasien sebelumnya tidak pernah mengalami gangguan jiwa. Pasien dibawa oleh saudara kandungnya ke Yayasan Pemenang Jiwa Sumatera tahun 2018.1 tahun pertama pasien sering p mengalami halusinasi dengan melihat mahluk halus ketika mau tidur. Keluarga pasien tidak ada yang pernah mengalami gangguan jiwa. Pasien mengatakan kakak kandung nya membenci dirinya sehingga membuat usaha pasien menjadi gagal dengan menguna guna pasien. pasien berfikir bahwa saudara membenci dirinya nya kerena dia telah membuat saudara kecelakaan saat bekerja sehingga membuat tanagan saudara kandungnya terpotong .pasien juga mengatakan bahwa saudaranya ingin menguasai hartanya dari ATM sampai harta lainya sehingga membuat pasien.

Masalah Keperawatan: Koping individu inefektif

\subsection{Fisik}


Pasien tidak memiliki keluhan fisik, saat dilakukan pemeriksaan tanda-tanda vital, didapatkan hasil TD : 120/80 mmHg ; N : 80x/i ; S : 36, $5^{\circ} \mathrm{C} ; \mathrm{P}: 20 \mathrm{x} / \mathrm{i}$. Pasien memiliki tinggi badan $175 \mathrm{~cm}$ dan berat badan $65 \mathrm{Kg}$.

\subsection{Psikososial}

\subsubsection{Genogram}

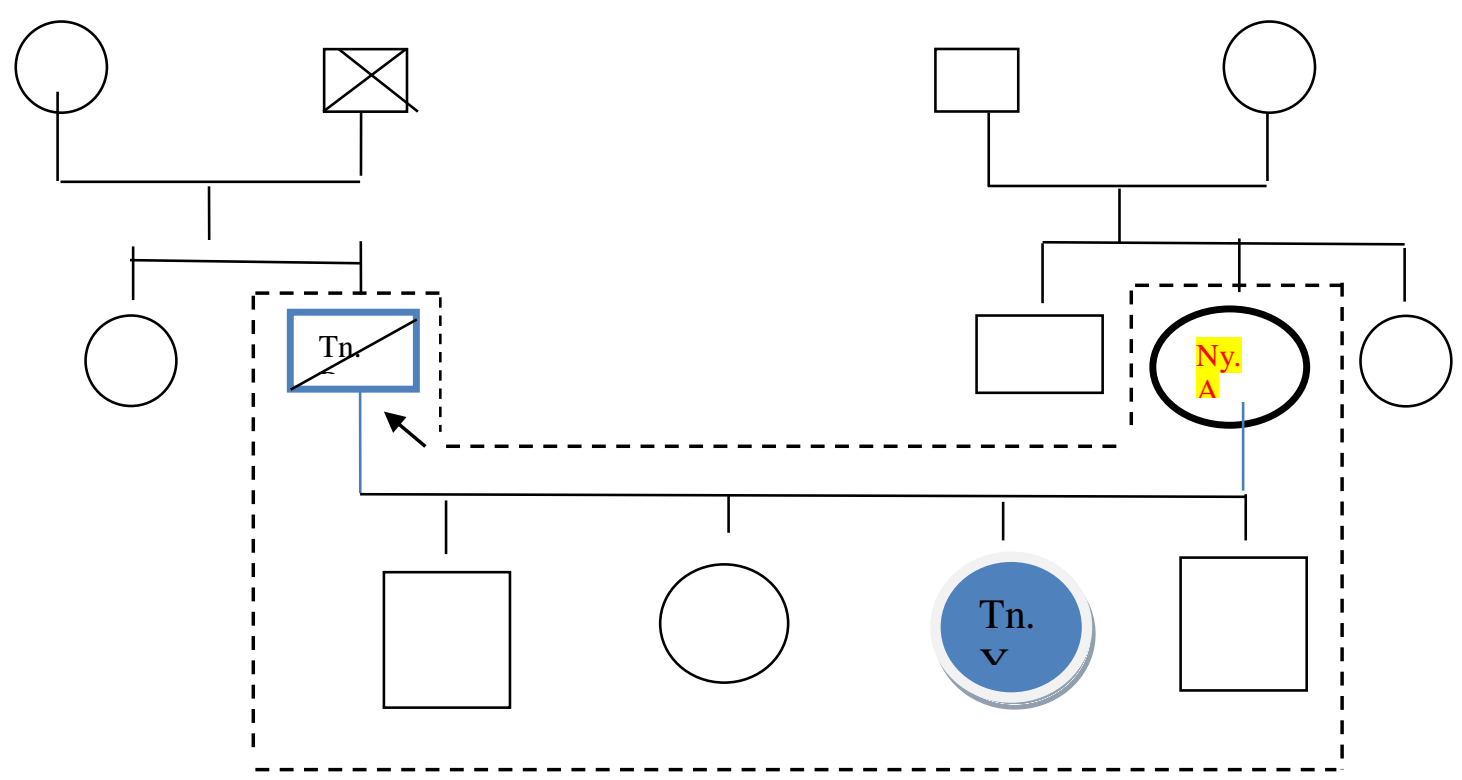

Penjelasan :

Pasien anak ketiga dari 4 bersaudara, pasien berinisial Tn.Y ,anak yatim ayahnya meninggal saat usia pasien 23 tahun.

Keterangan :

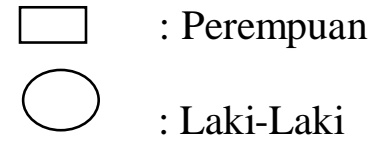

Tn. : Pasien

--- Tinggal dalam satu rumah

$\searrow$ : Meninggal 


\subsubsection{Konsep diri}

a. Gambaran diri : Dengkul pasien mengalami kecacatan akibat terjatuh

b. Identitas : Pasien anak ke 3 dari 4 bersaudara, pasien hanya lulusan SMA yang saat ini dirawat di Yayasan Pemenang Jiwa Sumatera

c. Peran : Pasien belum berkeluarga dan masing lajang, pasien sebelunya tinggal bersama saudarany

d. Ideal diri : Pasien sedang sakit sehinga di antarkan ke yayasan pemenangan jiwa tersebut

e. Harga diri : Pasien merasa malu dan dirinya dibenci oleh saudaranya kerna dianggap telah membuat tangan saudaranya Masalah keperawatan:Gangguan konsep diri : harga diri rendah

\subsubsection{Hubungan sosial}

Pasien mengganggap semua orang ada di yayasan adalah orang yang sangat baik. Pasien ingin selalu mengikuti kegiatan di yayasan tersebut tetapi terhalang karena kondisi lutut yang cedera

\subsubsection{Spiritual}

a. Nilai dan Keyakinan : Pasien beragama kristen dan yakin dengan agamanya.

b. Kegiatan Ibadah : Ibadah 3 kali sehari. Yaitu pagi 2 kali, sekitar pukul 6 pagi dan pukul 10 pagi, selanjutnya jam 7 malam.

\subsubsection{Status Mental}

1. Penampilan

Pasien rapi dan bersih, pasien mandi $2 \mathrm{x}$ sehari menggunakan shampo ,sabun dan menggosok gigi nya.

2. Pembicaraan

Pasien saat diberikan pertanyaan dan kadang- kadang menjawab tidak nyambung.

Masalah keperawatan : Waham (Waham Kebesaran) 


\section{Aktivitas Motorik}

Pasien tampak tegang ketika diajak berkomunikasi

4. Alam perasaan

Pasien sedih dan mau karena tinggal di yayasan, terlebih keluarga jarang datang menjenguk.

Masalah keperawatan : Harga Diri Rendah

5. Afek

Afek pasien datar, pasien menjawab pertanyaan dari perawat

6. Interaksi selama wawancara

Selama komunikasi, pasien selalu mempertahankan bahwa dirinya adalah pengusaha sukses .

7. Persepsi

Pasien tidak mengalami gangguan persepsi sensori

8. Proses Pikir

Pasien berfikir seperti Flight of idea. Pasien pada saat di ajak berbicara tidak nyambung, menjawabnya tidak tepat pada fokus pertanyaan dari pembicaraan.

Masalah keperawatan : Waham (Waham Kebesaran)

9. Isi piker

Pasien mengatakan memiliki usaha ketring yang besar dan kolam lele yang luas dan sudah mengexport keluar negri

Masalah Keperawatan : Waham (Waham Kebesaran)

10. Tingkat kesadaran

Pasien tidak mengalami gangguan orientasi, pasien mengenali waktu, orang dan tempat.

11. Memori

Pasien tidak ada gangguan daya ingat. Pasien mampu mengingat suatu hal.

12. Tingkat konsentrasi berhitung

Pasien mampu berkonsentrasi cukup baik dan pasien mampu berhitung sederhana tanpa bantuan orang lain. 
13. Kemampuan penilaian

Pasien mampu menilai mana yang lebih diutamakan dalam mengambil keputusan.

14. Daya tilik diri

pasien mengatakan bahwa usaha ketringnya sudah berjalan lancar dan kolam lele nya sudak eksport keluar negri Masalah keperawatan : Waham (Waham Kebesaran)

\subsection{Mekanisme Koping}

Pasien mengalami mekanisme koping adaptif yaitu pasien dapat berbicara baik dengan orang lain dan berkooperatif.

\subsection{Masalah Psikososial dan Lingkungan}

Pasien mengatakan sering mengikuti kegiatan di Yayasan tersebut

\subsection{Pengetahuan Kurang Tentang Gangguan Jiwa}

Pasien kurang mengetahui tentang gangguan jiwa yang di alaminya dan pasien tau apa obat yang dikonsumsinya.

\subsection{Analisis Data}

\begin{tabular}{|l|l|c|}
\hline No & \multicolumn{1}{|c|}{ Data } & Masalah Keperawatan \\
\hline $\mathbf{1}$ & $\begin{array}{l}\text { Subjektif : Pasien mengatakan bahwa ia } \\
\text { adalah pengusaha ketring dan ternak lele } \\
\text { yang luas. } \\
\text { Objektif :1.ketika diajak berwawancara } \\
\text { terkadangan jawaban pasien tidak sesuai } \\
\text { dengan pertanyaan yang diberikan perawat } \\
\text { 2.pasien banyak bicara } \\
\text { 3.mengulang ulang perkataanya yang } \\
\text { sudah pernah diucap }\end{array}$ & \\
\hline
\end{tabular}




\begin{tabular}{|l|l|l|}
\hline 2 & $\begin{array}{l}\text { Subjektif : Pasien merasa keluarganya } \\
\text { tidak membutuhkan dia lagi dan merasa } \\
\text { minder dengan orang lain karena di rawat } \\
\text { dirumah sakit jiwa } \\
\text { Objektif : } \\
\text { 1. Paien tampak malu pandangan tidak } \\
\text { fokus kelawan bicara, dan tampak sedih saat } \\
\text { di kaji, } \\
\text { 2.tatapan mata kosong }\end{array}$ & Harga diri rendah \\
\hline $\mathbf{3}$ & $\begin{array}{l}\text { Subjektif : } \\
\text { Pasien mengatakan ia sangat menyesal } \\
\text { kerena telah membuat saudaranya menjadi } \\
\text { cacat sehingga membenci dirinya dan } \\
\text { usaha yang ketring yang dibuat gagal } \\
\text { Objektif: } \\
\text { 1.Pasien tampak merenung dan bingung } \\
\text { jika tidak di ajak bicara } \\
\text { 2.pasien tampak sedih dengan keadaan nya } \\
\text { sekarang }\end{array}$ & Koping individu \\
\hline
\end{tabular}

\subsection{Daftar Masalah Keperawatan}

a. Gangguan Proses Pikir : Waham (Waham Kebesaran)

b. Gangguan Konsep Diri : Harga Diri Rendah

c. Koping Individu Inefektif 


\subsection{Pohon Masalah}

Kerusakan Komunikasi Verbal<smiles>C1CCCCC1</smiles>

Perubahan proses pikir: Waham<smiles>C1CCCCC1</smiles>

Gangguan Konsep Diri : Harga Diri Rendah<smiles>C1CCCCC1</smiles>

Koping Individu Inefektif

\subsection{Diagnosa Prioritas}

Gangguan proses pikir : Waham

\subsection{Intervensi Keperawatan}

\begin{tabular}{|l|l|l|}
\hline No & \multicolumn{1}{|c|}{ Masalah Keperawatan } & \multicolumn{1}{|c|}{ Intervensi } \\
\hline \multirow{2}{*}{ Gangguan proses pikir : Waham } & SP 1: \\
& Latihan orienatsi realitas: orientasi orang,waktu \\
& tempat dan lingkungan sekitar \\
& SP 2: \\
& Minum obat secara teratur \\
& SP 3: \\
& Melatih cara pemenuhan kebutuhan dasar \\
& SP 4: \\
& Melatih kemampuan positif yang dimiliki \\
\hline & \\
\hline & Sp 1: \\
\hline & Mengidentifikasi kemampuan dan aspek \\
\hline
\end{tabular}




\begin{tabular}{|l|l|}
\hline Harga Diri Rendah & positif yang dimiliki oleh pasien \\
& Sp2: \\
& 1. Menilai kemampuan yang dapat digunakan \\
& 2. Menetapkan / memilih kegiatan sesuai \\
kemampuan & \\
3. Melatih kegiatan sesuai kemampuan yang \\
dipilih 2 \\
Sp 3: \\
Melatih kegiatan sesuai kemampuan yang \\
dipilih 2 \\
Sp 4: \\
Melatih kegiatan sesuai kemampuan yang \\
dipilih 3
\end{tabular}




\subsection{Implementasi Dan Evaluasi}

\begin{tabular}{|c|c|c|}
\hline Hari/tgl & Implementasi & Evaluasi \\
\hline $\begin{array}{l}\text { Senin } 15 \text { maret } \\
2021\end{array}$ & $\begin{array}{l}\text { 1. Data : Tanda dan gejala : inkoheren, Defensive, wajah tegang } \\
\text { dan jawaban dari pertanyaan flight of idea, banyak berbicara } \\
\text { 2. Diagnosa Keperawatan Gangguan proses pikir : Waham } \\
\text { 3. Tindakan keperawatan: } \\
\text { Sp } 1 \text { Gangguan proses pikir : Waham } \\
\text { 1. Mengidentifikasi penyebab, tanda dan gejala, serta akibat } \\
\text { dari waham } \\
\text { 2. Latihan orienatsi realitas: orientasi orang,waktu tempat dan } \\
\text { lingkungan sekitar } \\
\text { Sp } 2 \text { Gangguan proses pikir : Waham } \\
\text { 1. Minum obat secara teratur } \\
\text { Menjelaskan tentang obat yang diminum (6 benar) } \\
\text { Mendiskusikan manfaat minum obat dan kerugian tidak } \\
\text { minum obat dengan pasien - Melatih pasien cara minum } \\
\text { obat secara teratur }\end{array}$ & $\begin{array}{l}\text { S : Pasien tampak senang dan terseyum } \\
\text { ketika diajak berbicara } \\
\mathrm{O} \text { :Pasien mampu melakukan latihan } \\
\text { orienatsi realitas: orientasi orang, waktu } \\
\text { tempat dan lingkungan sekitar } \\
\text { Pasien mampu menyebutkan obat dan } \\
\text { fungsinya dengan baik dan minum obat } \\
\text { dengan bantuan perawat } \\
\text { A : Gangguan proses pikir Waham (+) } \\
\text { P : Latihan: } \\
\text { - Orientasi realita : panggil nama, } \\
\text { - orientasi waktu, orang dan } \\
\text { tempat/lingkungan. } \\
\text { - Minum obat secara teratur } 2 \times 1 \text { /hari } \\
\text { Risperidon } 2 \text { mg ( } 2 \text { x } 1 \text { ) Clorozapine } 25 \\
\text { mg (1x1) }\end{array}$ \\
\hline
\end{tabular}




\begin{tabular}{|c|c|c|}
\hline & $\begin{array}{l}\text { 4. RTL : Sp } 3 \text { Waham } \\
\text { 1. Menjelaskan cara memenuhi kebutuhan klien yang tidak } \\
\text { terpenuhi akibat wahamnya dan kemampuan memenuhi } \\
\text { kebutuhannya } \\
\text { 2. Melatih cara memenuhi kebutuhan dasar klien yang tidak } \\
\text { terpenuhi akibat }\end{array}$ & \\
\hline $\begin{array}{l}\text { Rabu } 17 \text { /03/2021 } \\
\text { Pukul 10:00 WIB }\end{array}$ & $\begin{array}{l}\text { 1. Data : Tanda dan gejala : banyak berbicara, inkoheren, } \\
\text { Defensive, dan jawaban dari pertanyaan flight of ideapasien } \\
\text { selalu mengulang ulang perkataanya } \\
\text { 2. Diagnosa Keperawatan } \\
\text { Ganguan proses pikir :Waham } \\
\text { 3. Tindakan keperawatan: } \\
\text { Sp } 3 \text { Gangguan proses pikir : Waham } \\
\text { 1. Menjelaskan cara memenuhi kebutuhan pasien yang tidak } \\
\text { terpenuhi akibat wahamnya dan kemampuan memenuhi } \\
\text { kebutuhannya } \\
\text { 2. Melatih cara memenuhi kebutuhan dasar pasien yang tidak } \\
\text { terpenuhi akibat wahamnya dan kemampuan memenuhi }\end{array}$ & $\begin{array}{l}\text { S : pasien terlihat Senang } \\
\text { O : Pasien mampu memenuhi kebutuhan } \\
\text { dasar dengan mandiri seperti : } \\
\text { - Makan 3xsehari } \\
\text { - Mandi 2xsehari } \\
\text { - Olahraga 2xsehari } \\
\text { A : Waham (+) } \\
\text { P : Pemenuhan kebutuhan dasar: } \\
\text { - Makan 3xsehari } \\
\text { - Mandi 2xsehari } \\
\text { - Olahraga 2xsehari }\end{array}$ \\
\hline
\end{tabular}




\begin{tabular}{|c|c|c|}
\hline & $\begin{array}{l}\text { kebutuhannya } \\
\text { 4.RTL: Sp } 4 \text { Waham } \\
\text { a. Menjelaskan kemampuan positif yang dimiliki klien } \\
\text { b. Mendiskusikan kemampuan positif yang dimiliki klien } \\
\text { c. Melatih kemampuan positif yang dipilih }\end{array}$ & \\
\hline $\begin{array}{l}\text { Jumat } \\
\text { /03/2021 } \\
\text { Pukul 10:00 WIB }\end{array}$ & $\begin{array}{l}\text { 1. Data : Tanda dan gejala : banyak berbicara, inkoheren,, } \\
\text { Defensive, dan jawaban dari pertanyaan flight of ideapasien } \\
\text { selalu mengulang ulang perkataanya } \\
\text { 2. Diagnosa Keperawatan } \\
\text { Waham } \\
\text { 3. Tindakan keperawatan : } \\
\text { Sp } 4 \text { Gangguan proses pikir : Waham } \\
\text { 1. Menjelaskan kemampuan positif yang dimiliki pasien } \\
\text { 2. Mendiskusikan kemampuan positif yang dimiliki pasien } \\
\text { 3. Melatih kemampuan positif yang dipilih } \\
\text { 4. RTL: Sp2 Harga Diri Rendah: } \\
\text { Ganguan konsep diri :waham : Follow up dan evaluasi SP 1-4 }\end{array}$ & $\begin{array}{l}\text { S : pasien terlihat Senang } \\
\text { O :Pasien mampu melakukan kemampuan } \\
\text { positif yang dimiliki dengan motivasi } \\
\text { Dengan mandiri } \\
\text { - Menggambar } \\
\text { - Menulis } \\
\text { A : Waham (+) } \\
\text { P :Pasien melakukan kemampuan positif } \\
\text { yang dimiliki : } \\
\text { - Menggambar } \\
\text { - Menulis }\end{array}$ \\
\hline
\end{tabular}




\begin{tabular}{|c|c|c|}
\hline $\begin{array}{l}\text { Jumat 22/03/2021 } \\
\text { Pukul10:00 WIB }\end{array}$ & $\begin{array}{l}\text { 1. Data : Tanda dan gejala Hilang kepercayaan diri, merasa gagal } \\
\text { karena tidak mampu mencapai keinginan sesuai ideal diri, } \\
\text { perasaan tidak berharga, tidak berarti dan rendah diri yang } \\
\text { berkepanjanganan } \\
\text { Paien tampak malu pandangan tidak fokus kelawan bicara, dan } \\
\text { tampak sedih saat di kaji, } \\
\text { 2. Diagnosa Keperawatan: Harga Diri Rendah } \\
\text { 3. Tindakan keperawatan: } \\
\text { Sp } 1 \text { Harga Diri Rendah : } \\
\text { Mengidentifikasi kemampuan dan aspek positif yang dimiliki } \\
\text { pasien } \\
\text { 4. RTL: Sp2 Harga Diri Rendah: } \\
\text { a. Menilai kemampuan yang dapat digunakan } \\
\text { b. Menetapkan atau memilih kegiatan sesuai kemampuan } \\
\text { c. Melatih kegiatan sesuai kemampuan yang dipilih }\end{array}$ & $\begin{array}{l}\text { S : Antusias dan bersemangat } \\
\text { O : Klien mampu Mengidentifikasi aspek } \\
\text { positif yang dimiliki pasien yaitu berdoa } \\
\text { dan bersyukur. } \\
\text { A : Harga Diri Rendah (+) } \\
\text { P : Klien selalu memulai segala aktivitas } \\
\text { nya dengan bersyukur dan Doa. }\end{array}$ \\
\hline $\begin{array}{l}\text { Rabu 24/03/2021 } \\
\text { Pukul10:00 WIB }\end{array}$ & $\begin{array}{l}\text { 1. Data : Tanda dan gejala : Hilang kepercayaan diri, merasa gagal } \\
\text { karena tidak mampu mencapai keinginan sesuai ideal diri, } \\
\text { perasaan tidak berharga, tidak berarti dan rendah diri yang } \\
\text { berkepanjangan }\end{array}$ & $\begin{array}{l}\mathrm{S}: \text { Senang dan antusias } \\
\mathrm{O} \text { :Klien mampu memilih dan melatih } \\
\text { kegiatan sesuai kemampuan yaitu menulis } \\
\text { A : Harga Diri Rendah }(+)\end{array}$ \\
\hline
\end{tabular}




\begin{tabular}{|c|c|c|}
\hline & $\begin{array}{l}\text { 2. Diagnosa Keperawatan Harga Diri Rendah } \\
\text { 3. Tindakan keperawatan: } \\
\text { Sp } 2 \text { Harga Diri Rendah : } \\
\text { a. Menilai kemampuan yang dapat digunakan } \\
\text { b. Menetapkan atau memilih kegiatan sesuai kemampuan } \\
\text { c. Melatih kegiatan sesuai kemampuan yang dipilih } 1 \\
\text { 4. RTL: Sp } 3 \text { : } \\
\text { Melatih kegiatan sesuai kemampuan yang dipilih } 2\end{array}$ & $\begin{array}{l}\mathrm{P}: \text { Klien melatih kemampuan menulis } \\
\text { yang dimiliki nya }\end{array}$ \\
\hline $\begin{array}{l}\text { Rabu 24/03/2021 } \\
\text { Pukul10:00 WIB }\end{array}$ & $\begin{array}{l}\text { 1. Data : Tanda dan gejala : Hilang kepercayaan diri, merasa gagal } \\
\text { karena tidak mampu mencapai keinginan sesuai ideal diri, } \\
\text { perasaan tidak berharga, tidak berarti dan rendah diri yang } \\
\text { berkepanjanga } \\
\text { 2. Diagnosa Keperawatan Harga Diri Rendah } \\
\text { 3. Tindakan keperawatan: } \\
\text { Sp } 3 \text { Harga Diri Rendah : Melatih kegiatan sesuai kemampuan } \\
\text { yang dipilih } 2 \\
\text { 4. RTL: Sp } 4 \text { : } \\
\text { Melatih kegiatan sesuai kemampuan yang dipilih } 3\end{array}$ & $\begin{array}{l}\text { S : Senang dan antusias } \\
\text { O: Klien mampu melatih kegiatan sesuai } \\
\text { kemampuan yaitu menyuci piring. } \\
\text { A : Harga Diri Rendah (+) } \\
\text { P : } \\
\text { a. Berdoa, } \\
\text { b. Mengikuti ibadah } \\
\text { c. menulis }\end{array}$ \\
\hline
\end{tabular}




\begin{tabular}{|c|c|c|}
\hline & $\begin{array}{l}\text { 1. Data : Tanda dan gejala : Hilang kepercayaan diri, merasa gagal } \\
\text { karena tidak mampu mencapai keinginan sesuai ideal diri, } \\
\text { perasaan tidak berharga, tidak berarti dan rendah diri yang } \\
\text { berkepanjangan } \\
\text { 2. Diagnosa Keperawatan Harga Diri Rendah } \\
\text { 3. Tindakan keperawatan: Sp Harga Diri Rendah : Melatih } \\
\text { kegiatan sesuai kemampuan yang dipilih } 3 \\
\text { 4. RTL : } \\
\text { Harga Diri Rendah : Follow up dan evaluasi SP 1-4 }\end{array}$ & $\begin{array}{l}\text { S : Senang } \\
\mathrm{O}: \text { Melatih kegiatan sesuai kemampuan } \\
\quad \text { yang dipilih yaitu menyapu rumah } \\
\text { A : Harga diri rendah }(+) \\
\mathrm{P}: \\
\text { a. Berdoa, Mengikut ibadah } \\
\text { b. Menulis cerita } \\
\text { c. Berolahraga }\end{array}$ \\
\hline
\end{tabular}




\section{BAB 4 \\ PEMBAHASAN}

Setelah penulis melaksanakan asuhan keperawatan kepada Tn.Y dengan waham di Yayasan Pemenang Jiwa Sumatera Sumatera, maka penulis pada BAB ini akan membahas kesenjangan antara teoritis dengan tinjauan kasus. Pembahasan dimulai melalui tahapan proses keperawatan yaitu pengkajian, diagnosa keperawatan, perencanaan, pelaksanaan dan evaluasi.

\subsection{Tahap Pengkajian}

Selama pengkajian dilakukan pengumpulan data dari beberapa sumber, yaitu dari pasien dan tenaga kesehatan di Yayasan Pemenang jiwa . Penulis mendapat sedikit kesulitan dikarena pasien terkadang menjawab keluar dari konteks pertanyaan. penulis melakukan pendekatan kepada pasien melalui komunikasi teraupetik yang lebih terbuka membantu pasien untuk memecahkan perasaannya dan juga melakukan observasi kepada pasien. Adapun upaya tersebut yaitu:

1. Melakukan pendekatan dan membina hubungan saling percaya diri pada pasien agar pasien lebih terbuka dan lebih percaya dengan menggunakan perasaan.

2. Mengadakan pengkajian pasien dengan wawancara

3. Mengadakan pengkajian dengan cara membaca status, melihat buku rawatan dan bertanya kepada pegawai Yayasan Pemenang Jiwa Sumatera Sumatera

Dalam pengkajian ini, penulis tidak menemukan kesenjangan karena ditemukan hal sama seperti diteori: Menurut Herman (2011 dalam Prakasa, 2020) tanda dan gejala waham seperti menolak makan, tidak peduli terhadap perawatan diri, ekspresi wajah yang sedih/gembira/ketakutan, gerakan yang tidak terkontrol, mudah tersinggung, pembicaraan yang tidak sesuai dengan kenyataan dan juga bukan kenyataan, menghindar dari orang lain, mendominasi pembicaraan, dan berbicara kasar. 


\subsection{Tahap perencanaan}

Perencanaan dalam proses keperawatan lebih dikenal dengan rencana asuhan keperawatan yang merupakan tahap selanjutnya setelah pangkajian dan penentuan diagnosa keperawatan. Pada tahap perencanaan penulis hanya menyusun rencana tindakan keperawatan sesuai dengan pohon masalah keperawatan yaitu : Gangguan proses pikir Waham (Kelliat 2014).

Pada tahap ini antara tinjauan teoritis dan tinjaun kasus tidak ada kesenjangan sehingga penulis dapat melaksanakan tindakan seoptimal mungkin dan didukung dengan tersedianya sarana ruangan perawat yang baik dan adanya bimbingan dan petunjuk dari petugas kesehatan dari rumah sakit jiwa yang diberikan kepada penulis.Secara teoritis digunakan cara strategi pertemuan sesuai dengan diagnosa keperawatan yang muncul saat pengkajian. Adapun upaya yang dilakukan penulis yaitu :

1. Gangguan proses pikir : Waham

a. Mengidentifikasi penyebab waham

b. Mengidentifikasi tanda dan gejala waham

c. Mengidentifikasi akibat waham

d. Membantu pasien mempraktekkan Latihan orienatsi realitas: orientasi orang, waktu tempat dan lingkungan sekitar

e. Menjelaskan dan mengingatkan untuk minum obat secara teratur

f. Membantu pasien mempraktekkan cara pemenuhan kebutuhan dasar

g. Membantu pasien melatih kemampua positif yang positif

h. Mengevaluasi jadwal kegiatan harian pasien

\subsection{Tahap Implementasi}

Pada tahap implementasi mahasiswa hanya mengatasi masalah keperawatan dengan diagnosa keperawatan Gangguan proses pikir : Waham. Pada diagnosa keperawatan Gangguan proses pikir : Waham dilakukan strategi pertemuan yaitu mengidentifikasi penyebab, tanda dan gejala, serta akibat dari waham latihan orienatsi realitas: orientasi orang,waktu tempat dan lingkungan sekitar. Strategi pertemuan yang kedua yaitu anjurkan minum obar secara teratur, strategi pertemuan ketiga yaitu latihan dengan cara pemenuhan kebutuhan 
dasar strategi pertemuan ke empat yaitu latihan kemampuan positif yang dimiliki (Kelliat 2014)

\subsection{Tahap evaluasi}

Pada tinjauan kasus evaluasi yang dihasilkan adalah :

1. Pasien sudah dapat mengontrol dan mengidentifikasi waham

2. Pasien dapat mengendalikan waham dengan cara latihan orientasi realita

3. Pasien dapat mengendalikan waham dengan cara minum obat secara teratur

4. Pasien dapat mengendalikan waham dengan cara pemenuhan kebutuhan dasar

5. Pasien dapat mengendalikan waham dengan latihan kemampuan positif yang dimiliki. 


\section{BAB 5 \\ PENUTUP}

\subsection{Kesimpulan}

Setelah menguraikan tentang proses keperawatan pada Tn. Y dan disimpulkan bahwa pasien dapat mengontrol gangguan proses pikir : Waham dengan terapi yang di ajarkan oleh mahasiwa. Dimana pasien dapat melakukan latihan orientai realita, minum obat secara teratur, latihan cara pemenuhan kebutuhan dasar hingga pasien dapat melakukan kemampuan posiif yang dimiliki.

\subsection{Saran}

1. Bagi Mahasiswa

Hendaknya mahasiswa/i dapat melakukan askep sesuai dengan tahapantahapan dari Standar Operasional Prosedur (SOP) dengan baik dan benar yang diperoleh selama masa pendidikan baik di akademik maupun dilapangan praktek.

2. Bagi Pasien

Diharapkan pasien dapat menerapkan terapi yang telah diberikan baik secara medik maupun terapi keperawatan yang telah diajarkan demi percepatan penyembuhan penyakit dengan masalah gangguan jiwa. 


\section{DAFTAR PUSTAKA}

Dalami, E., Rochimah, N., Suryati, K. R., \& Lestari, W. (2009). Asuhan Keperawatan pasien dengan gangguan jiwa

Darmiyanti, A. (2012). Analisa Terapi Aktivitas Kelompok Sosialisasi Sesi Ii Pada Tn. A Dengan Gangguan Proses Pikir: Waham Studi Kasus di Ruang 23 Psikiatri RSUD Saiful Anwar Malang (Doctoral dissertation, University of Muhammadiyah Malang). http://eprints.umm.ac.id/id/eprint/29871

Eriawan, A. (2019). Asuhan Keperawatan Pada Pasien Tn “O” Yang Mengalami Bipolar Dengan Masalah Keperawatan Waham Paranoid Di Ruangan Palm Rumah Sakit Khusus Daerah Dadi Provinsi Sulawesi Selatan Tahun 2019.

Keliat, B. A., dkk. (2019). Asuhan Keperawatan Jiwa. Jakarta: Penerbit Buku Kedokteran EGC.

Keliat, B A. dkk. (2014). Keperawatan Kesehatan Jiwa Komunitas : CMHN(Basic Course). Jakarta : Buku Kedokteran EGC.

Keliat, B. A. (2009). Model praktik keperawatan profesional jiwa. Jakarta: EGC.

Keliat, B. A. (2016). Prinsip dan praktik keperawatan kesehatan jiwa stuart,indonesa ,ELSEVIER

Nurarif, A., dkk (2015). Aplikasi Asuhan Keperawatan Diagnosa Medis NANDA NIC - NOC. Yogyakarta : Media Ection.

Pardede, J. A., \& Siregar, R. A. (2016). Pendidikan Kesehatan Kepatuhan Minum Obat Terhadap Perubahan Gejala Halusinasi Pada Klienskizofrenia. Mental Health, 3(1).

Pardede, J. A., Keliat, B. A., \& Yulia, I. (2015). Kepatuhan dan Komitmen Klien Skizofrenia Meningkat Setelah Diberikan Acceptance And Commitment Therapy dan Pendidikan Kesehatan Kepatuhan Minum Obat. Jurnal Keperawatan Indonesia, 18(3), 157-166, https://doi.org/10.7454/jki.v18i3.419

Pardede, J. A., Simanjuntak, G. V., \& Laia, R. (2020). The Symptoms of Risk of Violence Behavior Decline after Given Prgressive Muscle Relaxation Therapy on Schizophrenia Patients. Jurnal Ilmu Keperawatan Jiwa, 3(2), 91-100. http://dx.doi.org/10.32584/jikj.v3i2.534

Prakasa, A., \& Milkhatun, M. (2020). Analisis Rekam Medis Pasien Gangguan Proses Pikir Waham dengan Menggunakan Algoritma C4. 5 di Rumah Sakit Atma Husada Mahakam Samarinda. Borneo Student Research (BSR), 2(1)8-15. 
Prastika, Y., Mundakir, S. K., \& Reliani, S. K. (2014). Asuhan Keperawatan Jiwa Pada Pasien Waham Kebesaran Dengan Diagnosa Medis Skizofrenia Hebefrenik Di Ruang Flamboyan Rs Jiwa Menur Surabaya (Doctoral dissertation, Universitas Muhammadiyah Surabaya)

Riskesdas (2018) Hasil Utama Riskesdas 2018 Kementerian Kesehatan Badan PenelitiandanPengembanganKesehatan.https://www.kemkes.go.id/res ources/do wnload/info-terkini/hasil-riskesdas2018.pdf

Saputri, S. F. M \& Mar'atus, M. (2021). Asuhan Keperawatan Jiwa Dengan Resiko Perilaku Kekerasan. Skripsi, Universitas Kusuma Husada Surakarta

Sofian, R. (2017). Asuhan Keperawatan jiwa dengan kasus waham kebesaran pada Tn. K di RSJ Radjiman Wediodiningrat Lawang (Doctoral dissertation, STIKes Maharani Malang).

Victoryna, F., Wardani, I. Y., \& Fauziah, F. (2020). Penerapan Standar Asuhan Keperawatan Jiwa Ners untuk Menurunkan Intensitas Waham Pasien Skizofrenia. Jurnal Keperawatan Jiwa, 8(1), 45-52. https://jurnal.unimus.ac.id/index.php/JKJ/article/view/5352/pd

WHO(2019). Schizophrenia .Diakses $10 \quad$ April 2020.

https://www.who.int/newsroom/fact-sheets/detail/schizophrenia

Yusuf, A., dkk. (2015). Buku ajar keperawatan kesehatan jiwa. Jakarta : Salemba.

Zahnia, S., \& Sumekar, D. W. (2016). Kajian epidemiologis skizofrenia. Jurnal Majority, 5(4), 160-166.

http://juke.kedokteran.unila.ac.id/index.php/majority/article/view/904

Zukna, N. A. M., \& Lisiswanti, R. (2017). Pasien dengan Halusinasi dan Waham Bizarre. JurnalMedula, 7(1),3842.

http://juke.kedokteran.unila.ac.id/index.php/medula/article/view/745 